\title{
Expression and Characterization of Aplysia Protein Kinase C: A Negative Regulatory Role for the E Region
}

\author{
Wayne S. Sossin, Xiaotang Fan, and Farzad Saberi \\ Department of Neurology and Neurosurgery, McGill University, Montreal Neurological Institute, Montreal, Quebec, \\ Canada H3A 2B4
}

The Aplysia nervous system contains two phorbol ester-activated protein kinase $\mathrm{C}$ isoforms, the $\mathrm{Ca}^{2+}$-activated $\mathrm{Apl} \mathrm{I}$ and the $\mathrm{Ca}^{2+}$-independent Apl II. Short-term applications of the facilitatory transmitter serotonin (5-HT) activates Apl I, but not Apl II. In contrast, Apl II, but not Apl I, can form an autonomous kinase. To investigate the biochemical characteristics of the Aplysia kinases that might underlie their differential activation, we expressed Apl I, Apl II, and two derivatives of Apl II with deletions in the amino-terminal 150 amino acid $E$ region in insect cells using the baculovirus system. Similar to nervous system extracts, expressed Apl II has more autonomous activity than Apl I. Removal of the E region lowered the amount of phosphatidylserine required for activation of Apl II, but did not remove the autonomous kinase activity. In addition, phosphatidylserine vesicles could sediment fusion proteins containing the $E$ region, consistent with a role for the $E$ region in lipid interactions. A partial deletion of the $E$ region modifies activation of Apl II by phorbol esters and oleic acid, suggesting that in the intact enzyme the $E$ region interacts with the phorbol ester-binding domain of the kinase. These results introduce a model whereby the $\mathrm{E}$ region acts as a negative regulator of $\mathrm{Apl}$ II activation and suggest that this inhibition may explain the inability of short-term applications of 5-HT to activate Apl II.

Key words: protein kinase C; Aplysia; learning and memory; synaptic plasticity; autophosphorylation; autonomous kinase
The protein kinase $\mathrm{C}$ family (PKC) is involved in multiple signal transduction pathways (Nishizuka, 1992). In the nervous system PKCs are associated with short- and long-term modulation of synaptic efficacy (Olds and Alkon, 1991; Schwartz, 1993). These isoforms can be subdivided into three types: $\mathrm{Ca}^{2+}$-activated PKCs $(\alpha, \beta, \gamma), \mathrm{Ca}^{2+}$-independent PKCs $(\delta, \epsilon$, $\eta, \theta)$, and atypical PKCs that are not activated by diacylglycerol $(\zeta, \iota / \lambda)$. All $\mathrm{Ca}^{2+}$-activated PKCs contain a domain, called $\mathrm{CalB}$, that binds phosphatidylserine in a $\mathrm{Ca}^{2+}$-dependent manner (Brose el al., 1992) and confers $\mathrm{Ca}^{2+}$-dependent activation to these isoforms (Kaibuchi et al., 1989). $\mathrm{Ca}^{2+}$-independent PKCs lack a CalB domain, but do contain a conserved region at the amino-terminal end of the protein named the $E$ region in PKC $\epsilon$ and PKC $\eta$ (Osada et al., 1990; Kruger et al., 1991; Land et al., 1994). A domain of the E region (E2) shows homology to the CalB domain (Sossin and Schwartz, 1993), suggesting that the $\mathrm{E}$ region may have a function analogous to the regulatory role of $\mathrm{CalB}$ in $\mathrm{Ca}^{2+}$-activated $\mathrm{PKCs}$.

In the marine mollusk Aplysia californica, the nervous system has only two phorbol ester-activated $\mathrm{PKC}$ isoforms, the $\mathrm{Ca}^{2+}$ activated Apl I, which contains a CalB domain, and the $\mathrm{Ca}^{2+}$ independent Apl II, which contains an E region (Kruger et al., 1991; Sossin et al., 1993). The simplicity of isoform distribution, coupled to physiological information about the role of protein kinase $\mathrm{C}$ in regulating synaptic transmission in Aplysia (Braha et al., 1990, 1993; Sacktor and Schwartz, 1990; Ghirardi et al., 1992;

\footnotetext{
Received June 1, 1995; revised Aug. 31, 1995; accepted Sept. 1, 1995.

This work was supported by Medical Research Council (MRC) of Canada Grant MT-12046 to W.S.S. (an MRC of Canada Scholar). We thank Emma Saffman, Todd Sacktor, Phil Barker, and Stefano Stifani for critically reading this manuscript.

Correspondence should be addressed to Dr. Wayne S. Sossin, Department of Neurology and Neurosurgery, McGill University, Montreal Neurological Institute, 3801 Rue University, Montreal, Quebec, Canada H3A 2B4.

Copyright (C) 1995 Society for Neuroscience $0270-6474 / 95 / 160010-09 \$ 05.00 / 0$
}

Sugita et al., 1992, 1994), makes this an ideal system for determining if different isoforms of PKC play unique physiological roles in regulating synaptic transmission.

There are isoform-specific differences in the activation of Apl I and Apl II. First, short-term applications of serotonin, a facilitating transmitter, activate Apl I, but not Apl II (Sossin and Schwartz, 1992; Sossin et al., 1994). Second, in Aplysia nervous system extracts, autonomous kinase activity (measured as the amount of phosphorylation of a substrate peptide in the absence of the PKC activators, phosphatidylserine and phorbol ester) can be immunoprecipitated largely by an antibody against Apl II, but not by an antibody against Apl I (Sossin et al., 1994), suggesting that a fraction of Apl II molecules are active in the absence of PKC activators. Thus, in the Aplysia nervous system, Apl II is both more resistant to stimulation and more able to form an autonomous kinase than is Apl I. To investigate further the biochemical properties of Apl I and Apl II, we have expressed the kinases in SF9 cells using the baculovirus system. Many of the properties of these kinases observed in nervous system extracts arc maintaincd in partially purified preparations from SF9 cells. Furthermore, results from expression of derivatives of Apl II with full or partial deletions of the $E$ region suggest that the $E$ region acts to negatively regulate Apl II by interacting with its phorbol esterbinding domain.

\section{MATERIALS AND METHODS}

Construction of plasmids. A complete Apl I cDNA was constructed in Bluescript $\mathrm{KS}^{-}$(Stratagene, La Jolla, CA) by ligating two cDNA clones (2-1 encoding the N-terminal region of Apl I and 15-1 encoding the C-terminal region of Apl I; (Kruger et al., 1991)) at their common Rg/II site. A complete Apl II cDNA was constructed in Bluescript $\mathrm{SK}^{+}$(Stratagene) by ligating two cDNA clones (9-1 encoding the $\mathrm{C}$-terminal region and eps-5 containing the $\mathrm{N}$-terminal region (Kruger et al., 1991)) at their common BspHI site. 
To construct baculovirus transfer vectors, the Apl I cDNA was removed from SK by partially digesting with $B a m \mathrm{HI}$ and inserted into the BamHI site of the pBlueBacIII vector (Invitrogen, San Diego, CA). In this construct, 400 bp of $3^{\prime}$-untranslated region from the Apl I cDNA were removed. The Apl II cDNA was removed from SK by digesting with $E c o$ RI and inserted into pBlueBacIII after partial digestion of pBlueBacIII at the EcoRI site in the polylinker of the construct. The Apl II $\Delta \mathrm{E}$ deletion was constructed by ligating an XmnI-EcoRV fragment from the Apl II cDNA to the fusion vector pAC360 (Invitrogen) after filling in the Bam HI site with Klenow. The junction was confirmed by sequencing and results in the replacement of the $E$ region by amino acids 1-10 of the baculovirus polyhedron protein. The Apl II $\Delta \mathrm{E} 2$ construct was generated with a two-step mutagenic procedure using the polymerase chain reaction (PCR). First-round PCR used the Apl II CDNA as a template and either the outside $5^{\prime}$ primer $5^{\prime}$-TCTAGAACTAGTGGATC and the inside $3^{\prime}$ primer 5 '-GGCCGCCATCTGCGAGGCTTTTTCTTTCGT or the inside $5^{\prime}$ primer $5^{\prime}$-TCGCAGATGGCGGCCGCAATTCCACCCGACGAG and the outside 3' primer 5'-CATTTGGTGACTATATGCTGGTGA. The products from the first-round synthesis were combined and used as the template for the second-round synthesis using the two outside primers. The resultant product was then cut with $E c o$ RI and $K p n I$ and reinserted into the full length cDNA. This resulted in the joining of residue 292 to residue 445 or amino acids SQM to amino acids AAI with an intervening alanine to insert a NotI site to mark the deletion. The deletion was sequenced over the entire amplified region, and the mutated Apl II was inserted into the pBlueBacIII baculovirus transfer vector as described above.

To construct fusion protein vectors, the eps-5 Apl II cDNA (Kruger et al., 1991) was excised with $S t u I$ and $P_{s t I}$ and ligated to the pRIT2T vector (Pharmacia, Piscataway, NJ) cut with SmaI and $P$ stl. The amino-terminal fragment of Apl II, which ends at amino acids DDV (residue 502), was removed from pRIT2T with $E$ coRI, and the ends were filled in with Klenow and ligated into the pMALC-R2* vector cut with $X m n I$ to generate the construct pMALC-E1-E3. The pMALC-R2* vector is the pMALC-R2 vector (New England Biolabs, Beverly, MA) cut with Bam HI, filled in with Klenow, and religated to create a stop codon. The pMALC-E1-E3 construct was digested with NlaIV and SspI and religated to form pMALC-E1-E3APY. pMALC-E1-E3AE2 was constructed using the same mutagenesis strategy described above, except with outside primers from the pMALC vector 5'-GGTCGTCAGACTGTCGA and 5'-CGCCAGGGTTTTCCCAGTCACGAC. A SmaI-XmnI fragment from the Apl II full length cDNA was ligated into the pMALC-R2 XmnI site to make the pMALC-E1-E4 construct, and a $S s p I-X m n I$ fragment was ligated into the pMALC-R2 XmnI site to make the pMALC-E2-E4 vector.

Baculovirus expression. Spodoptera frugiperda (SF9; Invitrogen) cells were grown in suspension cultures with supplemented Grace's media (Life Technologies, Inc., Gaithersburg, MD) and 10\% fetal bovine serum (Life Technologies). The baculovirus transfer vectors were cotransfected with linearized baculovirus (Invitrogen) into SF9 cells using cationic liposomes following standard procedures (Invitrogen), and the resultant blue colonies were plaque-purified. For Apl II $\Delta \mathrm{E}$, positive plaques were isolated by serial dilution. Positive colonies were confirmed by PCR and by immunoblotting with anti-Apl I or anti-Apl II antibodies (Kruger et al., 1991; Sossin et al., 1993). High titer viral stocks $\left(10^{8}-10^{9}\right.$ plaqueforming units $[\mathrm{PFU}] / \mathrm{ml}$ ) were generated as described (Summers and Smith, 1988)

Purification of PKCs. Typically $100 \mathrm{ml}$ of SF9 cells $\left(2 \times 10^{6}\right.$ cells $\left./ \mathrm{ml}\right)$ were infected with $1 \times 10^{9}$ PFUs of baculovirus and incubated for $64 \mathrm{hr}$ for optimal expression of PKCs. Cells were then pelleted and resuspended in $20 \mathrm{ml}$ of ice-cold homogenization buffer $(10 \mathrm{mM}$ Tris $8.0,1 \mathrm{mM}$ EGTA, $10 \mathrm{mM} \mathrm{MgCl}$, $5 \mathrm{~mm}$ 2-mercaptoethanol, $20 \mu \mathrm{g} / \mathrm{ml}$ aprotinin, 5 mM benzamidinc, and $0.1 \mathrm{~mm}$ leupeptin). All further steps were performed at $4^{\circ} \mathrm{C}$. Cells were sonicated $6 \times 10 \mathrm{sec}$ with a probe sonicator (Vibracell, Sonics and Materials, Danbury, CT) and debris pelleted by centrifugation in a Sorvall RCB2 centrifuge at $12,000 \times g$ in an SS34 rotor. The supernatant was filtered through a $0.22 \mu \mathrm{M}$ filter, diluted to 50 $\mathrm{ml}$ with Buffer A (20 mM Tris- $\mathrm{HCl}$, pH 8.0, $0.5 \mathrm{~mm}$ EGTA, $0.5 \mathrm{~mm}$ EDTA, $10 \mathrm{~mm}$ 2-mercaptoethanol, 10\% glycerol), and loaded onto a MemSep DEAE 1000 cartridge previously equilibrated in Buffer A at a flow rate of $3 \mathrm{ml} / \mathrm{min}$ using a ConSepLC100 system (Millipore, Milford, MA). After $50 \mathrm{ml}$ of wash with Buffer A, PKCs were eluted with a linear gradient from 0 to $300 \mathrm{~mm} \mathrm{NaCl}$. Fractions positive for PKC activity as detectcd by a kinasc assay werc pooled, and ammonium sulfate was added to a final concentration of $2.4 \mathrm{M}$. The sample was then diluted to
$50 \mathrm{ml}$ with Buffer B $\left(100 \mathrm{mM} \mathrm{NaHPO}_{4}, \mathrm{pH} 6.8,0.5 \mathrm{~mm}\right.$ EGTA, $0.5 \mathrm{~mm}$ EDTA, $10 \mathrm{~mm}$ 2-mercaptoethanol, $10 \%$ glycerol, $\left.2.4 \mathrm{M}\left(\mathrm{NH}_{4}\right)_{2} \mathrm{SO}_{4}\right)$ and loaded onto a $5 \mathrm{ml}$ hydrophobic interaction cartridge (HIC; Bio-Rad, Richmond, $\mathrm{CA}$ ), washed with $20 \mathrm{ml}$ of Buffer $\mathrm{B}$ and eluted with a linear gradient from 2.4 to $0 \mathrm{M}\left(\mathrm{NH}_{4}\right)_{2} \mathrm{SO}_{4}$ for $1 \mathrm{hr}$ at a flow rate of $1 \mathrm{ml} / \mathrm{min}$. The positive fractions were pooled and either dialyzed against Buffer $\mathrm{C}$ (20 $\mathrm{mM} \mathrm{KHPO}_{4}$, pH 7.5, $0.5 \mathrm{~mm}$ EGTA, $0.5 \mathrm{~mm}$ EDTA, $10 \mathrm{~mm} \mathrm{2-}$ mercaptoethanol, and $10 \%$ glycerol) overnight or diluted into $50 \mathrm{ml}$ of Buffer C. The sample was then loaded onto a $5 \mathrm{ml}$ hydroxyapatite column cartridge (H^P, Bio-Rad) previously equilibrated with Buffer C. Proteins were eluted with a linear gradient from 20 to $500 \mathrm{mM} \mathrm{KHPO}_{4}$ for $40 \mathrm{~min}$ at a flow rate of $1 \mathrm{ml} / \mathrm{min}$. Positive fractions were pooled, concentrated 2-4 times by centrifugation in a Centricon-10 microconcentrator (Amicon, Beverly, MA), diluted in PKC storage buffer (50 mM Tris $8.0,100 \mathrm{mM}$ $\mathrm{NaCl}, 0.5 \mathrm{~mm}$ EDTA, $0.5 \mathrm{~mm}$ EGTA, $5 \mathrm{~mm} \beta$-mercaptoethanol, $10 \%$ glycerol), and concentrated again by centrifugation using Centricon-10. Samples were aliquoted and stored frozen at $-70^{\circ} \mathrm{C}$ or diluted with $50 \%$ glycerol and stored at $-20^{\circ} \mathrm{C}$. Kinase activity was stable for up to 6 months, but there was an approximately twofold decrease in stimulation by phorbol esters after freeze-thaw.

PKC assays. Assays were done as described (Sossin and Schwartz, 1992; Sossin et al., 1993). The reaction mixture $(30 \mu \mathrm{l})$ contained $50 \mathrm{~mm}$ Tris- $\mathrm{HCl}, \mathrm{pH} 7.5,10 \mathrm{~mm} \mathrm{MgCl}_{2}, 5 \mathrm{mM}$ EGTA, and $5 \mu \mathrm{M}$ Ae-pep (LNRRRGSMRRRVHQVNGH) in the presence or absence of $50 \mu \mathrm{g} / \mathrm{ml}$ of dioleol phosphatidylserine (Avanti, Alabaster, $\mathrm{AL}$ ), and $20 \mathrm{~nm}$ 12-0. tetradecanoyl-phorbol-13-acetate (TPA). Ae-pep is a synthetic peptide based on the pseudosubstrate peptide of Apl II, which is phosphorylated well by both Apl I and Apl II (Sossin and Schwartz, 1992; Sossin et al., 1993). After addition of $10 \mu \mathrm{l}$ of purified PKCs, diluted to remain in the linear range of the assay (Sossin and Schwartz, 1992), the reaction was started with $10 \mu \mathrm{l}$ of $\left[\gamma^{32} \mathrm{P}\right] \mathrm{ATP}$ (DuPont NEN, Boston, MA; $1 \mu \mathrm{Ci} ; 50$ $\mu \mathrm{M}$ final concentration). After $30 \mathrm{~min}$ at $20^{\circ} \mathrm{C}, 40 \mu \mathrm{l}$ of the $50 \mu \mathrm{l}$ reaction mixture was spotted onto a Whatman phosphocellulose paper disk, which was washed in $100 \mathrm{ml}$ of $2 \%(\mathrm{w} / \mathrm{v})$ ATP. The disks were then rinsed four times for 5 min with $0.425 \%(\mathrm{v} / \mathrm{v})$ phosphoric acid, and radioactivity was counted by scintillation. Each value is the average of duplicate assays.

For experiments to determine activation by oleic acid or TPA, a concentrated reaction mixture $(20 \mu \mathrm{l})$ was added to $10 \mu \mathrm{l}$ of the appropriate concentration of TPA or oleic acid. Stock concentrations of oleic acid (Nu Chek Prep, Elysian, MN) and phosphatidylserine were stored in small batches in chloroform. Before each experiment they were dried under $\mathrm{N}_{2}$ gas, suspended in water, vortexed vigorously, and sonicated either in a cup sonicator (FS3; Fisher Scientific, Ottawa, Ontario) for phosphatidylserine or with a probe sonicator $(2 \times 10 \mathrm{sec})$ for oleic acid. In some experiments oleic acid was resuspended in ethanol after drying and then diluted from the ethanol stock into water. The mixed micelle assay to determine activation by phosphatidylserine was performed as described (Hannun and Bell, 1987) with 2 mole percent dioctylglycerol $\left(\mathrm{dIC}_{8}\right)$ and $0.3 \%$ Triton X-100.

Autophosphorylation was done using the same procedure but with a higher specific activity of ATP ( $4 \mu \mathrm{Ci}$ in $50 \mu \mathrm{M}$ ATP) and a higher concentration of phosphatidylserine $(150 \mu \mathrm{g} / \mathrm{ml})$. Autophosphorylations were carricd out for $10 \mathrm{~min}$, at which point the incorporation rate was linear with time (data not shown).

Sedimentation assay. Fusion proteins were purified by affinity chromatography on amylose columns (New England Biolabs). For the sedimentation assay, fusion protein $(2 \mu \mathrm{M})$ was incubated in $100 \mu \mathrm{l}$ of $50 \mathrm{~mm}$ Tris- $\mathrm{HCl}, \mathrm{pH} 7.5,50 \mathrm{mM} \mathrm{NaCl}, 10 \mathrm{mM} \mathrm{MgCl}_{2}, 10 \mathrm{mM}$ 2-mercaptoethanol in the presence or absence of $100 \mu \mathrm{g} / \mathrm{ml} 90 \%$ dioleol phosphatidylserine/ $10 \%$ dioleol phosphatidylcholine vesicles (Princeton Lipids, Princeton, NJ) $(9: 1 \mathrm{w} / \mathrm{w})$. After $20 \mathrm{~min}$ at $20^{\circ} \mathrm{C}$, the vesicles were sedimented at $100,000 \times g$ in a TL-100 centrifuge (Beckman, Palo Alto, CA) for $30 \mathrm{~min}$, and the supernatants and pellets separated on $10 \%$ sodium dodecyl sulfate (SDS)-Laemmli gels and stained with Coomassie. Experiments using $\left[{ }^{14} \mathrm{C}\right]$ phosphatidylcholine as a marker demonstrated $>90 \%$ sedimentation of vesicles using this approach (Quest et al., 1994) (data not shown). Gels were quantified using a Java imaging system (Jandel Scientific, San Rafael, CA)

Other procedures. SDS-polyacrylamide gels $(8.5 \%)$ and immunoblotting were carried out as described (Sossin et al., 1993). The antibody to Apl II was raised against a carboxyl-terminal peptide (Kruger et al., 1991) and thus should recognize all constructs equally. 


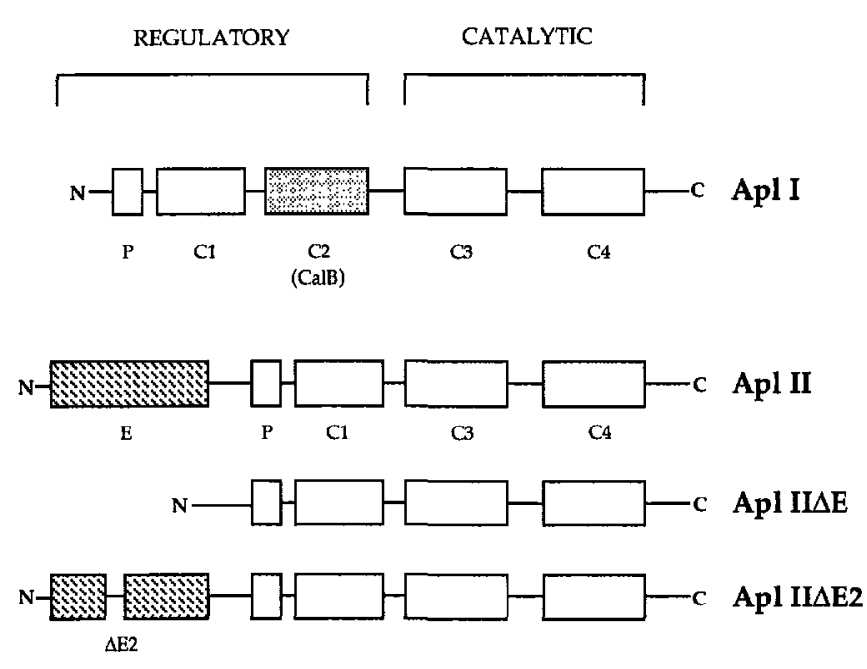

Figure 1. Domain structure of PKCs. PKCs are made up of conserved domains ( $\mathrm{C}$ regions) that are separated by variable domains which are distinct for each isoform. The catalytic domain that phosphorylates substrates is made up of the $\mathrm{C} 3$ and $\mathrm{C} 4$ domain and is similar among all PKCs. The regulatory portion of the molecule contains the $\mathrm{P}$ (pseudosubstrate) domain, which interacts with the catalytic domain to inhibit kinase activity, and the $\mathrm{C} 1$ phorbol ester/diacylglycerol binding domain, which regulates enzyme activity. $\mathrm{Ca}^{2+}$-activated PKCs such as Apl I contain a $\mathrm{C2}$ (or CalB) domain that confers the ability of the enzymes to be activated by $\mathrm{Ca}^{2+}$. $\mathrm{Ca}^{2+}$-independent PKCs contain a conserved amino-terminal region, which in Apl II is named the $E$ region because of its conservation to vertebrate Epsilon and Eta PKCs. In Apl II $\Delta \mathrm{E}$, the $\mathrm{E}$ region is replaced by amino acids $1-10$ of the baculovirus polyhedrin protein. In Apl II $\Delta E 2,51$ amino acids from the middle of the $E$ domain with sequence homology to the CalB domain are deleted.

\section{RESULTS}

\section{Expression and purification of Aplysia PKCs}

We constructed baculovirus transfer vectors for Apl I, Apl II, and two derivatives of Apl II: (1) Apl II $\Delta \mathrm{E}$, which encodes a protein that has the E region deleted, and (2) Apl II $\Delta E 2$, which encodes a protein that has a partial deletion in the $E$ region removing the domain that shows homology to CalB (Fig. 1). The transfer vectors were used to produce recombinant baculovirus for expression of the PKCs in SF9 cells, because SFY cells have little or no detectable PKC activity that would interfere with these experimonts (Patcl and Stabcl, 1989) (data not shown). Exprcssion of the Aplysia kinases was confirmed by immunoblotting (data not shown), and the kinases were partially purified over DEAE, hydrophobic interaction, and hydroxyapatite columns (Table 1, Fig. 2). After purification, the expressed kinases are the major Coomassie-stained band in the preparation, but are not homogeneous in the final preparation (Fig. 2).

In extracts of Aplysia nervous system, the majority of autonomous kinase activity (measured as the amount of phosphorylation of a substrate peptide in the absence of the PKC activators, phosphatidylserine and phorbol ester) can be immunoprecipitated by an antibody to Apl II (Sossin et al., 1994). Consistent with this finding, the percentage of autonomous activity in purified preparations from SF9 cells was fivefold greater for Apl II than for Apl I (Table 2). Apl II $\Delta \mathrm{E}$ and Apl II $\Delta \mathrm{E} 2$ preparations had a similar amount of autonomous activity when measured as activity per unit of immunoreactive protein, demonstrating that the $E$ region is not responsible for the autonomous activity of Apl II (Table 2). The autonomous activity did not result from proteolysis in the hinge region and formation of a constitutively active fragment of Apl II
(Schaap and Parker, 1990; Baxter et al., 1992), because this product was separated from intact PKCs during purification (data not shown). The autonomous activity was not attributable to activation of the enzyme by using the pseudosubstrate-derived peptide as a substrate, because a fivefold difference in autonomous activity between Apl I and Apl II also was observed when a peptide from the myelin basic protein was used as a substrate. It is possible that the regulatory region of Apl II is more easily denatured than Apl I, and that this accounts for a higher basal activity. If this were true, one might expect that after storage at $-70^{\circ} \mathrm{C}$, the autonomous activity would increase. Although we did see an increase in the percentage of autonomous activity after thawing, this was the same for both Apl I and Apl II and appears to be because of a reduction in the amount of activation by phorbol esters rather than an increase in the amount of autonomous enzyme. These results demonstrate that the autonomous activity of Apl II in Aplysia nervous system extracts can also be observed in the expressed kinase.

\section{Activation of expressed proteins by phosphatidylserine}

A major difference between vertebrate $\mathrm{Ca}^{2+}$-activated and $\mathrm{Ca}^{2+}$ independent PKCs is that $\mathrm{Ca}^{2+}$-independent $\mathrm{PKCs}$ require higher levels of phosphatidylserine for activation in the mixed micelle assay, an assay that is commonly used to determine the level of lipids required for PKC activation (Hannun et al., 1986; Hannun and Bell, 1987; Schaap and Parker, 1990). Similar to vertebrate PKCs, the $\mathrm{Ca}^{2+}$-indepcndent Apl II requires larger amounts of phosphatidylserine in this assay than does the $\mathrm{Ca}^{2+}$-activated Apl I (Fig. $3 A$ ). Unlike vertebrate PKCs, $\mathrm{Apl} \mathrm{I}$ is $\mathrm{Ca}^{2+}$-activated but not completely $\mathrm{Ca}^{2+}$-dependent in the mixed micelle assay, because Apl I can be fully activated even in the presence of $5 \mathrm{~mm}$ EGTA. $\mathrm{Ca}^{2+}$ ions do decrease the amount of phosphatidylserine required for Apl I activation, but not for Apl II (Fig. $3 A$ ) (data not shown) confirming their identities as $\mathrm{Ca}^{2+}$-activated and $\mathrm{Ca}^{2+}$. independent isoforms.

Removal of the $\mathrm{E}$ region reduces the requirement of Apl II for phosphatidylserine. Using the mixed micelle assay, Apl II $\Delta \mathrm{E}$ and Apl II $\Delta E 2$ were both fully activated at lower levels of phosphatidylserine than Apl II (Fig. 3B). Moreover, the level of phosphatidylserine required for activation of Apl II when the E region is removed is similar to that required for Apl $I$ in the absence of $\mathrm{Ca}^{2+}$ ions. Phosphatidylserine activates PKC mainly by binding to the $\mathrm{C} 1$ region and increasing the affinity of $\mathrm{C} 1$ for diacylglycerol (Quest et al., 1994). This result suggests that the requirement for phosphatidylserine binding to C1 is similar in Apl I and Apl II and that the difference in required phosphatidylserine levels between Apl I and Apl II can be explained by an additional requirement in Apl II for phosphatidylserine binding to the $\mathrm{E}$ region.

To determine whether the $E$ region directly interacts with phosphatidylserine, we constructed maltose-binding protein (MBP)-E region fusion proteins, affinity-purified the proteins from bacteria, and tested their ability to bind to phosphatidylserine using a sedimentation assay (Sossin and Schwartz, 1992; Quest et al., 1994). In this assay, vesicles made of $90 \%$ phosphatidylserine and $10 \%$ phosphatidylcholine are mixed with the test protein, and association with the vesicles is measured by the ability of the protein to cosediment with the vesicles after centrifugation at $100,000 \times g$. A fusion protein containing regions $E 1-E 3$ was sedimented by the vesicles, whereas maltosc-binding protein alone was not sedimented (Figs. 4, 5). The amount of protein sedimented $(40 \%)$ is similar to that reported for the known phosphatidylserine-interacting $\mathrm{C} 1$ region using a similar assay 


\begin{tabular}{|c|c|c|c|c|c|}
\hline Enzyme & Column fractions & $\begin{array}{l}\text { PKC activity } \\
\left(\mathrm{pmol} \cdot \min ^{-1} \cdot \mathrm{ml}^{-1}\right)\end{array}$ & $\begin{array}{l}\text { Specific activity } \\
\left(\mathrm{nmol} \cdot \mathrm{min}^{-1} \cdot \mathrm{mg}^{-1}\right)\end{array}$ & $\begin{array}{l}\text { Total protein } \\
(\mathrm{mg})\end{array}$ & $\begin{array}{l}\text { Yield } \\
\text { (\% start) }\end{array}$ \\
\hline \multirow[t]{4}{*}{ Apl I } & Start & 1.3 & 1.0 & 32 & 100 \\
\hline & DEAE $(75-150 \mathrm{~mm} \mathrm{NaCl})$ & 4.1 & 3.0 & 12 & 110 \\
\hline & $\mathrm{HIC}\left(600-200 \mathrm{mM} \mathrm{NH}_{4} \mathrm{SO}_{4}\right)$ & 2.5 & 6.4 & 2.4 & 48 \\
\hline & HAP $\left(100-150\right.$ mm $\left.\mathrm{KHPO}_{4}\right)$ & 5.4 & 22 & 0.2 & 15 \\
\hline \multirow[t]{4}{*}{ Apl II } & Start & 5.7 & 5.2 & 55 & 100 \\
\hline & DEAE (120-175 mM NaCl) & 6.1 & 7.2 & 13 & 32 \\
\hline & $\mathrm{HIC}\left(600-400 \mathrm{mM} \mathrm{NH}_{4} \mathrm{SO}_{4}\right)$ & 4.2 & 20 & 1.6 & 11 \\
\hline & HAP $\left(150-200 \mathrm{~mm} \mathrm{KHPO}_{4}\right)$ & 1.1 & 48 & 0.4 & 6 \\
\hline \multirow[t]{4}{*}{ Apl II $\Delta \mathrm{E}$} & Start & 0.5 & 0.4 & 17.4 & 100 \\
\hline & DEAE $(100-200 \mathrm{~mm} \mathrm{NaCl})$ & 0.8 & 0.6 & 5.2 & 43 \\
\hline & $\mathrm{HIC}\left(500-200 \mathrm{mM} \mathrm{NH}_{4} \mathrm{SO}_{4}\right)$ & 0.4 & 1.2 & 3.5 & 64 \\
\hline & HAP (150-200 mм $\left.\mathrm{KHPO}_{4}\right)$ & 1.8 & 18 & 0.3 & 9 \\
\hline \multirow[t]{4}{*}{ Apl II $\Delta \mathrm{E} 2$} & Start & 1.1 & 0.6 & 86 & 100 \\
\hline & DEAE $(100-200 \mathrm{~mm} \mathrm{NaCl})$ & 0.3 & 0.2 & 26 & 10 \\
\hline & $\mathrm{HIC}\left(500-200 \mathrm{mM} \mathrm{NH}_{4} \mathrm{SO}_{4}\right)$ & 0.4 & 1.2 & 2.6 & 6 \\
\hline & HAP $\left(175-225 \mathrm{~mm} \mathrm{KHPO}_{4}\right)$ & 0.1 & 2.6 & 0.8 & 4 \\
\hline
\end{tabular}

Summary of individual purifications for each of the expressed isoforms. No activity was detected after a mock infection with wild-type virus.

A

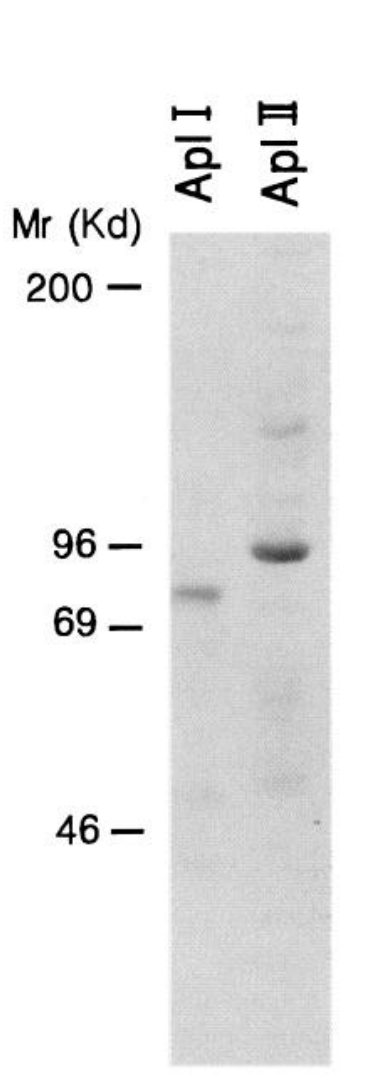

B

Apl II $\Delta \mathrm{E}$

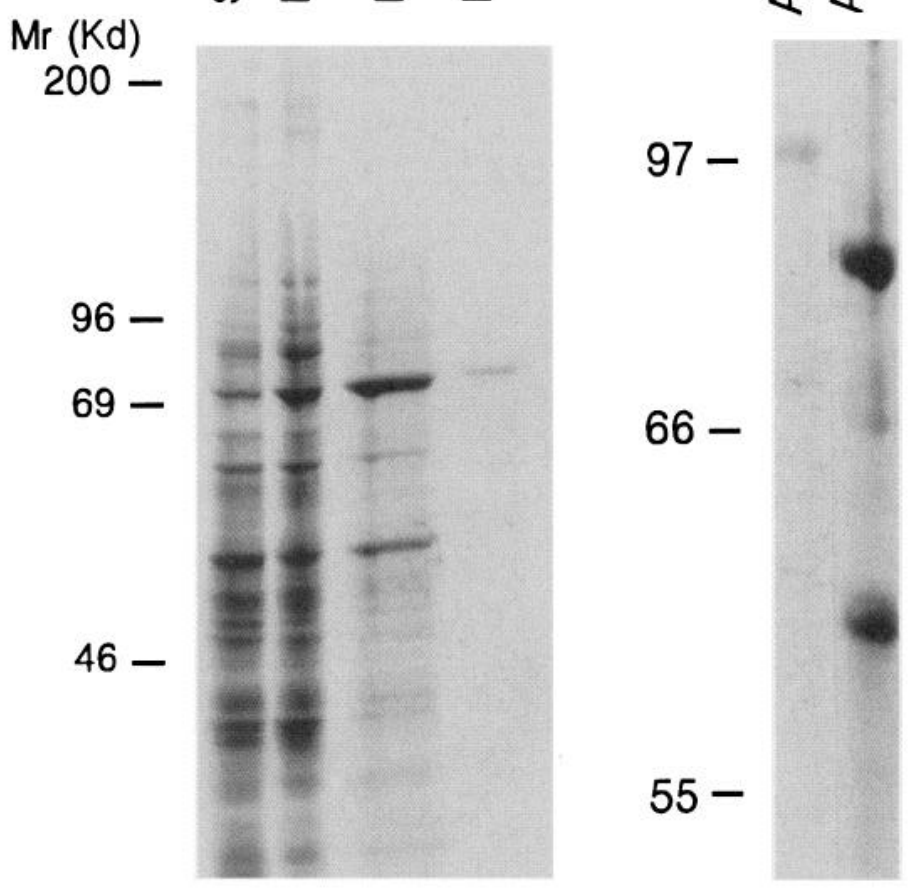

C

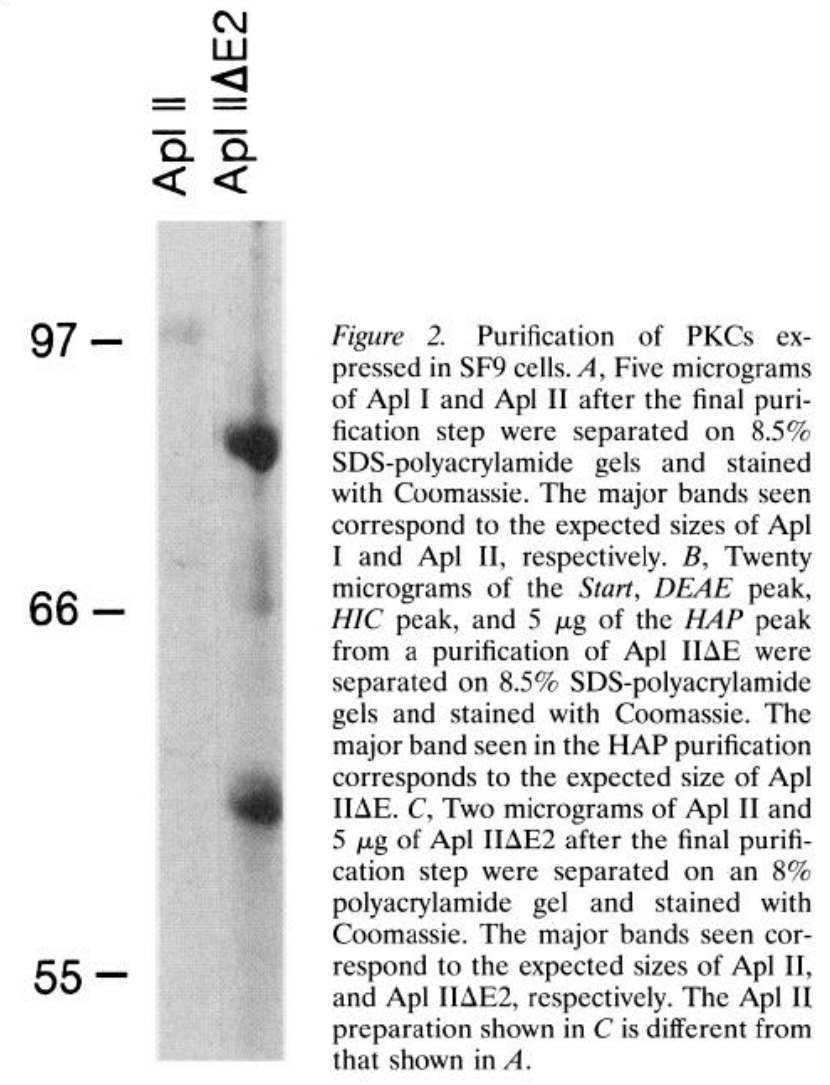

(Quest et al., 1994). Sedimentation in the assay was not dependent on the fusion partner because a separate fusion protein consisting of regions E1-E3 attached to Protein A also was sedimented (data not shown). Lowering the phosphatidylserine content from 90 to $20 \%$ did not significantly reduce sedimentation, showing that the interaction can occur at physiological levels of phosphatidylserine (data not shown). Surprisingly, a fusion protein that also contained E4 did not significantly bind to phosphatidylserine (Figs. 4, 5 ), suggesting that the conformation of the $\mathrm{E}$ region may be important for interactions with phosphatidylserine. This is consis- 


\section{Table 2. Autonomous PKC activity of expressed PKCs}

\begin{tabular}{llcl} 
Enzyme & $\begin{array}{l}\text { Autonomous activity } \\
\left(\mathrm{nmol} \cdot \mathrm{min}^{-1} \cdot \mathrm{mg}^{-1}\right)\end{array}$ & $\begin{array}{c}\text { Autonomous activity (\% } \\
\text { TPA stimulated activity) }\end{array}$ & $\begin{array}{c}\text { Autonomous activity (per } \\
\text { immunoreactive protein) }\end{array}$ \\
\hline Apl I & $0.8 \pm 0.2$ & $3 \pm 1$ & N.A. $^{a}$ \\
Apl II & $3.8 \pm 1.4$ & $16 \pm 5$ & 1 \\
Apl II $\Delta$ E & $5.0 \pm 2.3$ & $30 \pm 3$ & $1.5 \pm 0.7$ \\
Apl IISE2 & $1.2 \pm 1.1$ & $43 \pm 4$ & $0.9 \pm 0.1$
\end{tabular}

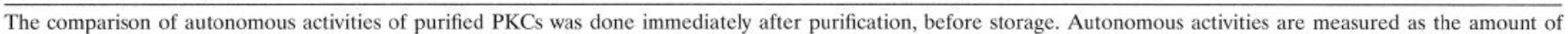

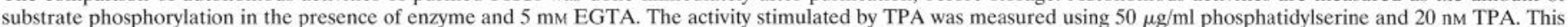

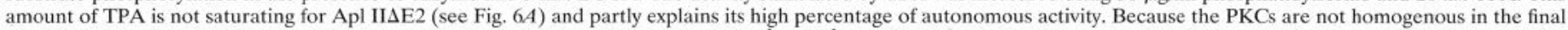

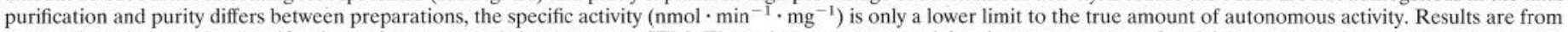

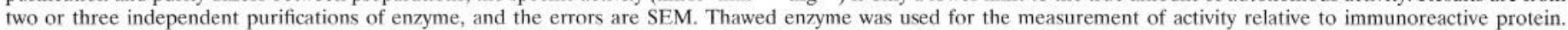

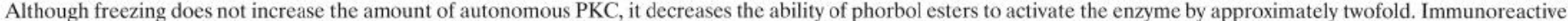

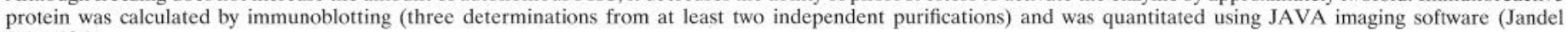
Scientific).

${ }^{a}$ N.A., not applicable.

A

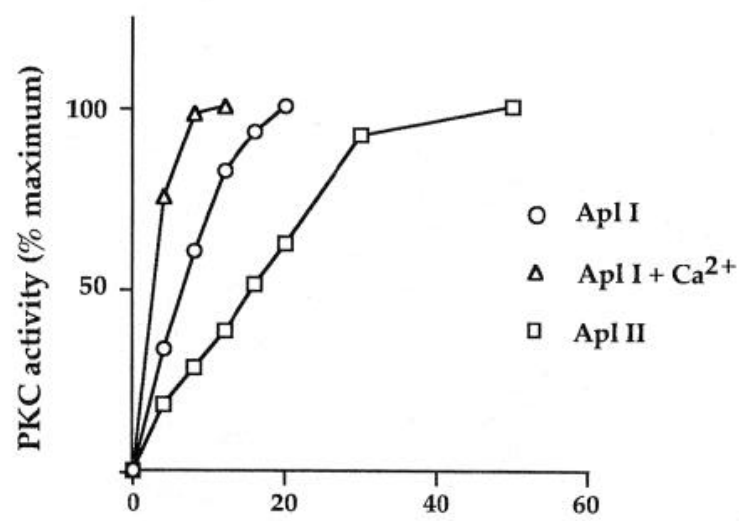

B

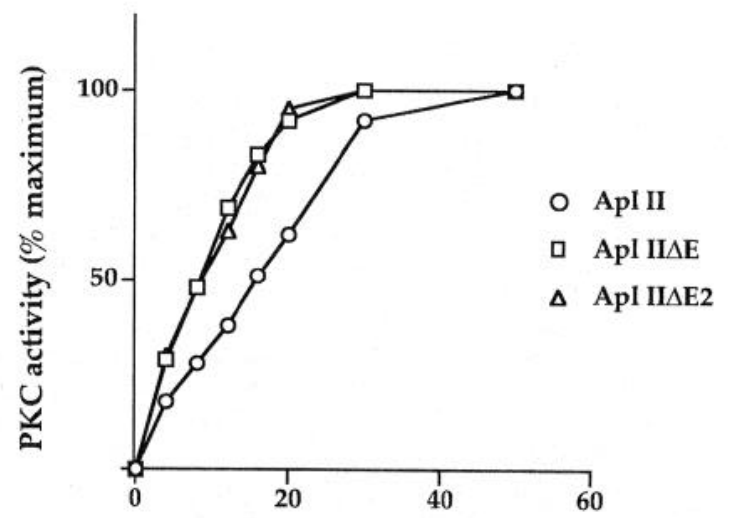

Phosphatidylserine (Mole percent)

Figure 3. Activation of expressed PKCs by phosphatidylserine. A, Mixed micelles of 2 mole percent dioctylglycerol $\left(\mathrm{dIC}_{8}\right)$ in Triton X-100 and varied amounts of dioleol phosphatidylserine were used to activate Apl I in the presence of $5 \mathrm{~mm}$ EGTA (०), Apl I in the presence of $150 \mu \mathrm{M} \mathrm{Ca}^{2+}$ $(\triangle)$, or Apl II in the presence of 5 mM EGTA. Maximal activity was 15 $\mathrm{nmol} \cdot \mathrm{min}^{-1} \cdot \mathrm{mg}^{-1}$ for Apl I and $10 \mathrm{nmol} \cdot \mathrm{min}^{-1} \cdot \mathrm{mg}^{-1}$ for Apl II ( $\square$ ). $B$, Mixed micelles of 2 mole percent $\mathrm{dIC}_{8}$ in Triton $\mathrm{X}-100$ and varied amounts of dioleol phosphatidylserine were used to activate Apl II (०), Apl II $\Delta \mathrm{E}(\square)$, or Apl II $\Delta \mathrm{E} 2(\triangle)$. Maximal activity was 10 $\mathrm{nmol} \cdot \mathrm{min}^{-1} \cdot \mathrm{mg}^{-1}$ for Apl II, $6 \mathrm{nmol} \cdot \mathrm{min}^{-1} \cdot \mathrm{mg}^{-1}$ for Apl II $\Delta \mathrm{E}$, and 6 $\mathrm{nmol} / \mathrm{min} / \mathrm{mg}$ for Apl II $\Delta \mathrm{E} 2$. The data shown are from one experiment; similar results were obtained in three additional cxpcriments.

tent with the fact that Apl II from nervous system extracts does not sediment with phosphatidylserine vesicles (Sossin and Schwartz, 1992).
A

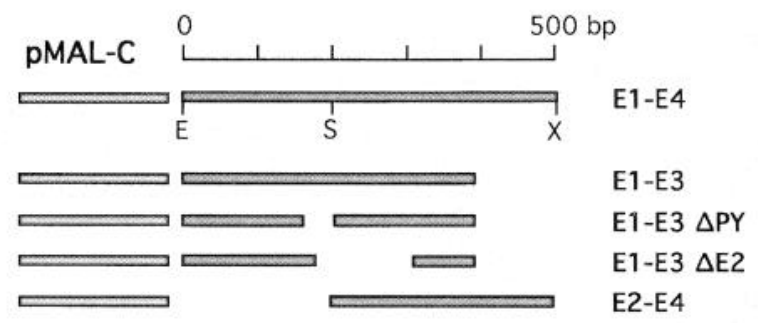

B

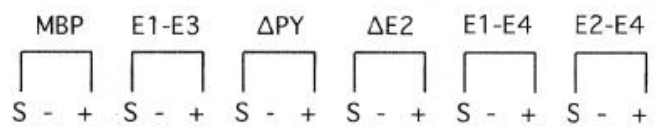

$\operatorname{Mr}(k D)$

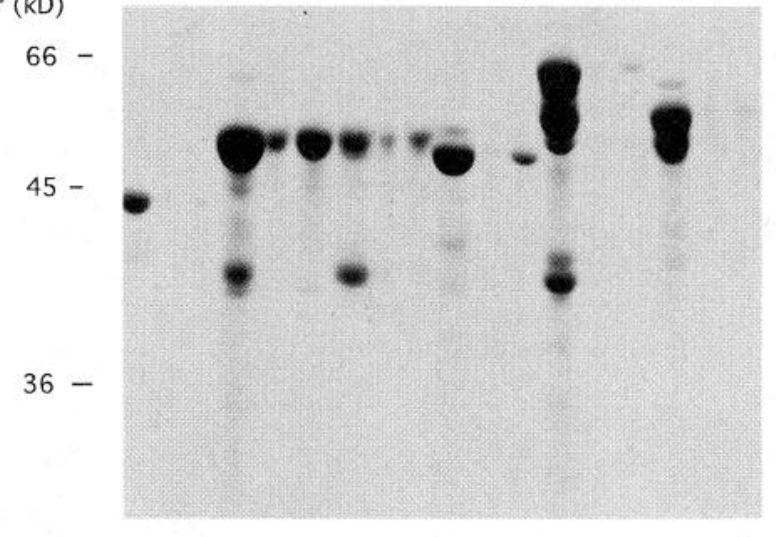

Figure 4. Sedimentation of $\mathrm{E}$ region fusion proteins by vesicles. $A$, Schematic of fusion protein constructs. The nomenclature E1-E4 (Sossin and Schwartz, 1993) highlights the blocks of conservation between E regions from different species. All PKC sequences were inserted at the $X m n \mathrm{I}$ site of the pMALC-R2 vector. $E, E c o$ RI; $S, S s p \mathrm{I} ; X, X m n \mathrm{I}$. See text for description of deletions. $B$, Affinity-purified pMALC fusion proteins ( 2 $\mu \mathrm{M})$ were sedimented in the absence $(-)$ or presence $(+)$ of $100 \mu \mathrm{g} / \mathrm{ml}$ of $90 \%$ phosphatidylserine/phosphatidylcholine vesicles, and the starting protein $(S)$ and the two pellets $(-)$ and $(+)$ were separated on $10 \%$ SDS-polyacrylamide gels and stained with Coomassie. Maltose-binding protein (MBP) is from the original pMALC-R2 vector and includes a $\beta$-galactosidase fusion protein. Similar results (quantitated in Fig. 5) are seen with protein from the pMALC-R2* vector (see Materials and Methods), which has an inserted stop codon in the polylinker and does not contain $\beta$-galactosidase sequences.

We attempted to localize further the region required for binding to phosphatidylserine. E2 shows homology to the CalB domain that can bind phosphatidylserine (Brose et al., 1992), and 


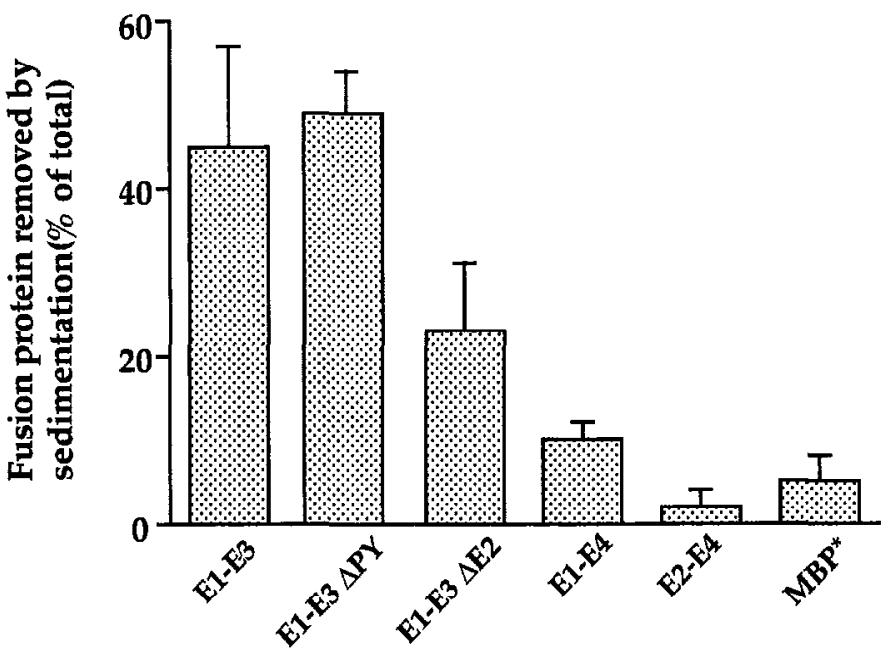

Figure 5. Quantitation of sedimentation of E region fusion proteins by vesicles. Results are the percentage of fusion protein sedimented specifically by the vesicles after subtracting the amount of fusion protein sedimented in the absence of vesicles (presumably because of aggregation). Errors are SEM from five independent experiments. The MBP in this experiment is from protein made with the pMALC-R2* vector (see Materials and Methods).

thus is a good candidate for this region. We therefore tested whether phosphatidylserine binding to the E region is dependent on the E2 domain. Two fusion proteins, one removing a highly conserved PY sequence (Sossin and Schwartz, 1993) and surrounding amino acids (E1-E3 $\triangle \mathrm{PY})$ and the other removing the entire E2 domain (E1-E3 $\Delta \mathrm{E} 2$ ), were tested in the assay. Deleting the PY sequence did not affect sedimentation by the vesicles, whereas removing $\mathrm{E} 2$ reduced, but did not eliminate, sedimentation in this assay (Figs. 4, 5). These experiments demonstrate a rolc for $\mathrm{E} 2$ in binding phosphatidylscrinc, but also indicatc that additional portions of the $E$ region can bind lipids in this assay.

\section{Activation of expressed PKCs by phorbol esters and oleic acid}

Phorbol esters activate PKCs by binding to the cysteine-rich $\mathrm{C} 1$ domain (Bell and Burns, 1991). Surprisingly, removal of the E2 domain from full length Apl II modified regulation of Apl II by phorbol esters, which is far removed from the $\mathrm{C} 1$ domain. Apl II $\Delta \mathrm{E} 2$ required higher concentrations of TPA to reach maximal activation and even at high concentrations was activated less than Apl II (Fig. 6A; Tables 2 and 3). This result suggests that the $\mathrm{E}$ region may interact with the phorbol ester-binding domain, $\mathrm{C}$. Removal of the entire $E$ region did not affect activation by phorbol esters, suggesting that the interaction between the $E$ region and $\mathrm{C} 1$ is inhibitory and therefore not required for highaffinity interaction of phorbol esters with Apl II.

The inability of phorbol esters to activate Apl II $\Delta E 2$ is not attributable to a general instability of the kinase, because activation of this deletion by a different PKC activator, oleic acid, was enhanced (Fig. 6B; Table 3). Similar to vertebrate PKCs (Koide et al., 1992; Khan et al., 1993), low concentrations of oleic acid activated the $\mathrm{Ca}^{2+}$-independent Apl II more than the $\mathrm{Ca}^{2+}$-activated Apl I (Fig. $6 B$ ). The E region is not responsible for this enhanced activation, as Apl II $\Delta \mathrm{E}$ was activated in a similar manner.

\section{Autophosphorylation of the expressed PKCs}

Activation of the expressed PKCs also was examined using an assay for autophosphorylation (Fig. 7). In autophosphorylation
A

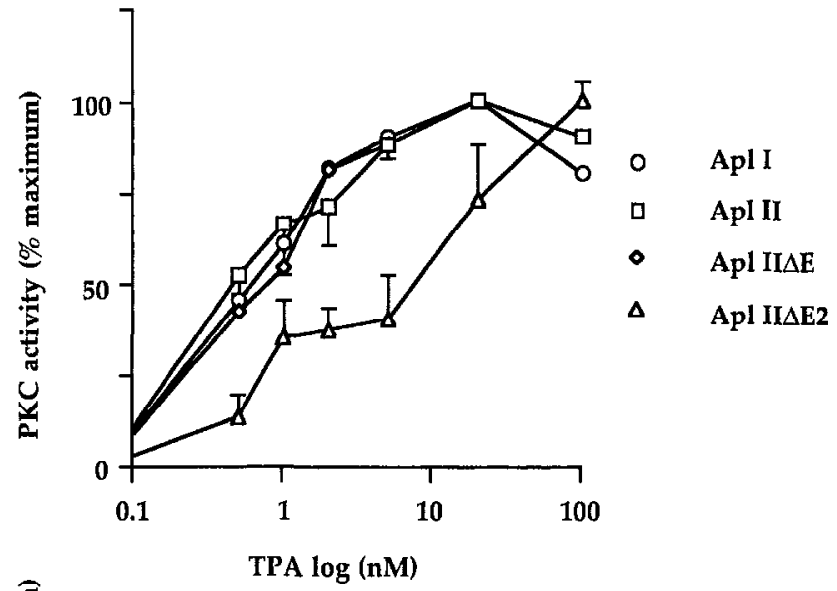

B

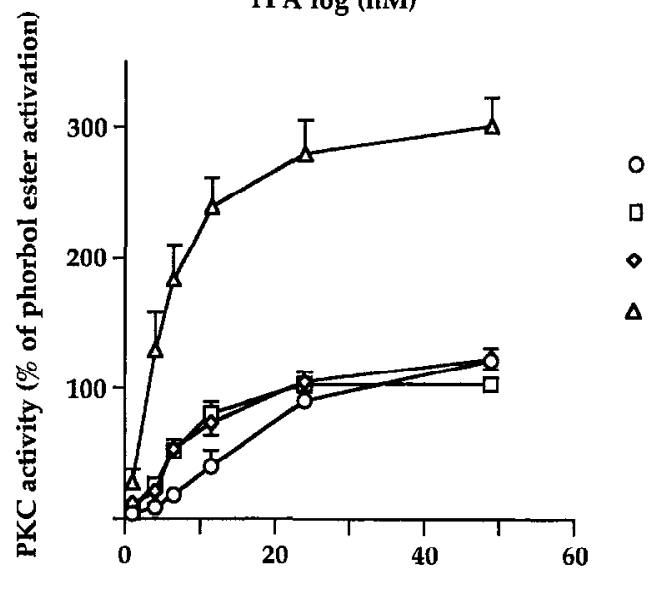

Apl I

Apl II

Apl II $\Delta \mathrm{E}$

Apl II $\Delta$ E2

Figure 6. A, Activation of expressed PKCs by TPA and oleic acid. Activation of Apl I (O), Apl II ( $\square$ ), Apl II $\Delta E(\diamond)$, and Apl II $\Delta E 2(\triangle)$ by various concentrations of TPA in the presence of $20 \mu \mathrm{g} / \mathrm{ml}$ dioleol phosphatidylserine and $5 \mathrm{mM}$ EGTA. Data are the average of four independent experiments. Maximal activities (in $\mathrm{nm} \cdot \mathrm{min}^{-1} \cdot \mathrm{mg}^{-1}$ ) were $10 \pm 4$ for Apl I, $12 \pm 2$ for Apl II, $8 \pm 1$ for Apl II $\Delta E$, and $6 \pm 1$ for Apl II $\Delta E 2$. Error bars are SEM; errors for Apl I and Apl II $\Delta E$ are not shown, but are smaller than the errors shown for Apl II. No further activation of Apl II $\triangle \mathrm{E} 2$ is seen at $400 \mathrm{~nm}$ TPA. B, Activation of Apl I (O), Apl II ( $\square$ ), Apl II $\Delta \mathrm{E}(\diamond)$, and $A \mathrm{pl}$ II $\Delta \mathrm{E} 2(\Delta)$ by various concentrations of oleic acid. Values are expressed as the percentage of activity stimulated by $50 \mu \mathrm{g} / \mathrm{ml}$ phosphatidylserine and $20 \mathrm{nM}$ TPA in the same experiment. These activities (in $\mathrm{nm} \cdot \mathrm{min}^{-1} \cdot \mathrm{mg}^{-1}$ ) were $11 \pm 2$ for Apl I, $10 \pm 2$ for Apl II, $10 \pm$ 2 for $A$ PI II $\Delta E$, and $3 \pm 1$ for Apl II $\Delta E 2$. Values are the average of four determinations. Error bars are SEM.

reactions, low concentrations of enzymes favor cis-autophosphorylation over trans-autophosphorylation, because the rate of cisautophosphorylation varies in a linear manner with concentration of the enzyme, whereas the rate of trans-autophosphorylation varies with the square of the concentration. In vertebrates, $\mathrm{Ca}^{2+}$. activated PKCs are cis-autophosphorylated after activation by phorbol esters but not after activation by oleic acid (Huang et al., 1986; El Touny et al., 1990). Consistent with this finding, at low concentrations of Apl I ( $<50 \mathrm{nM})$, we observed no detectable autophosphorylation after activation by oleic acid even though phorbol esters strongly stimulated autophosphorylation ( $\mathrm{Fig}$. 7). When higher concentrations of Apl I were used (>200 nM), we observed a strong autophosphorylation induced by oleic acid (data not shown), consistent with the activation of trans-autophosphorylation by oleic acid. In contrast, even at low concentrations of enzyme ( $<50 \mathrm{nM}$ ), autophosphorylation of Apl II was stimulated 


$\begin{aligned} & \text { Table 3. Comparison of affinities for PKC activators by expressed } \\
& \text { PKCs }\end{aligned}$
\begin{tabular}{llll} 
Ka (TPA) & $\begin{array}{l}\text { Ka (oleic } \\
\text { acid }(\mu \mathrm{M})\end{array}$ & $\begin{array}{l}\text { Autophosphorylation } \\
\text { (ratio oleic acid/TPA) }\end{array}$ \\
\hline Apl I & 0.6 & 52 & N.A. $^{a}$ \\
Apl II & 0.5 & 14 & $1.5 \pm 0.4$ \\
Apl II $\Delta \mathrm{E}$ & 0.7 & 17 & $0.1 \pm 0.03$ \\
Apl II $\Delta \mathrm{E} 2$ & 4 & 8 & $4.0 \pm 0.7$
\end{tabular}

The Ka for TPA was measured by fitting averaged data (Fig. 6) to double reciprocal plots. All data fit well to the double reciprocal plots $(r>0.95)$ except Apl II $\Delta \mathrm{E} 2(r$ $=0.92$ ). The double reciprocal plots for oleic acid (other than for Apl II $\Delta \mathrm{E} 2$ ) showed some positive cooperativity (El Touny et al., 1990), but were still estimated from double reciprocal plots of the average data (Fig. 6). Ratios for autophosphorylation were calculated after first subtracting the amount of phosphorylation seen without activators. Gels from autophosphorylation experiments using low concentrations of the expressed enzymes were either dried down or transferred to nitrocellulose and then quantitated using a phosphoimager (Molecular Dynamics, Sunnyvale, CA). Because no autophosphorylation was seen with oleic acid for Apl I, a ratio could not be quantitated. Errors are SEM from four independent experiments.

${ }^{a}$ N.A., not applicable.

by oleic acid at approximately the same rate as by phorbol esters (Fig. 7, Table 3). This result suggests that, in contrast to Apl I, Apl II can cis-autophosphorylate in the presence of oleic acid. Autophosphorylation of low concentrations of Apl II $\Delta \mathrm{E} 2$ is activated to a greater extent with oleic acid than by TPA, consistent with the finding that phosphorylation of substrates by Apl II $\Delta \mathrm{E} 2$ also is activated more strongly by oleic acid than by TPA (Fig. 6). Surprisingly, although Apl II $\Delta \mathrm{E}$ is activated equally by oleic acid and TPA for substrate phosphorylation, phorbol esters stimulate autophosphorylation of Apl II $\Delta \mathrm{E}$ to a much greater extent than does oleic acid. This may reflect that oleic acid-stimulated cisautophosphorylation requires some portion of the $\mathrm{E}$ region.

\section{DISCUSSION}

\section{Role of the E region in the regulation of ApI II}

Expression of Aplysia PKCs in the baculovirus system has confirmed the properties of the kinases inferred from nervous system extracts. Furthermore, our results indicate that the $\mathrm{E}$ region serves to negatively regulate Apl II, possibly through interaction with the phorbol ester-binding domain, $\mathrm{C} 1$.

Few previous studies have evaluated the role of the $\mathrm{E}$ region in the regulation of PKCs. For PKC $\eta$, removal of the $\mathrm{E}$ region did not affect substrate selectivity or fold activation by phorbol esters (Dekker et al., 1993b). Further removal or alteration of the pseudosubstrate did modulate substrate selectivity (Dekker et al., 1993a,b). Our results are consistent with this, because we did not observe large changes in the fold activation by phorbol esters after removal of the entire $\mathrm{E}$ region (Fig. $6 A$, Table 2), and also did not observe any differences in substrate specificity with Apl II $\Delta \mathrm{E}$ and Apl II $\Delta$ E2 (data not shown).

Our results show that in Aplysia, as reported previously for vertebrate PKCs (Schaap and Parker, 1990), a Ca ${ }^{2+}$-independent kinase, Apl II, requires higher levels of phosphatidylserine in the mixed micelle assay than does a $\mathrm{Ca}^{2+}$-activated kinase, Apl I. Our findings also suggest that this higher requirement is attributable to the presence of the $\mathrm{E}$ region, because deleting the $\mathrm{E}$ region reduced the amount of phosphatidylserine required to activate Apl II, and the E region directly interacted with phosphatidylserine in a sedimentation assay. Lipid interaction with the $\mathrm{E}$ region may be important in the regulation of $\mathrm{Ca}^{2+}$-independent PKCs. Although we have not addressed the specificity of phosphatidylserine in the interaction with the E region, if other lipids
Apl I
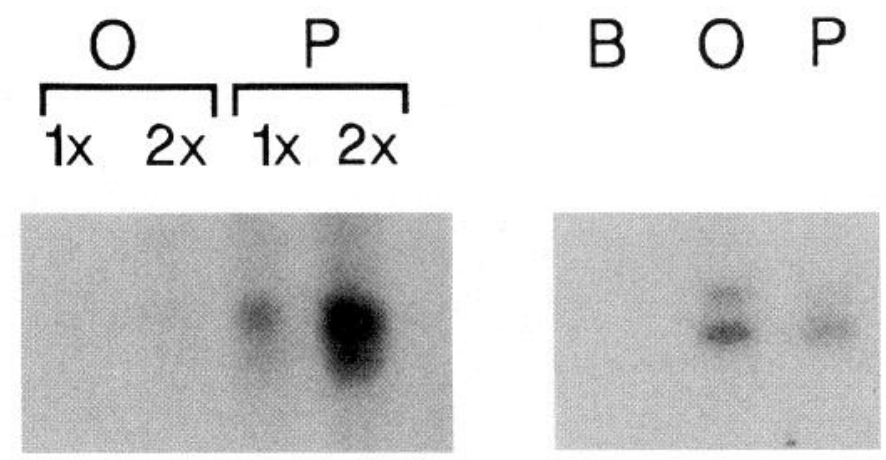

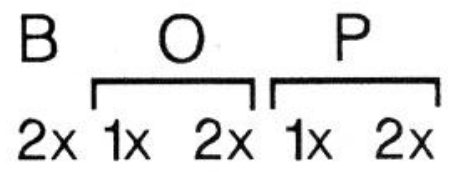

Apl II $\Delta \mathrm{E} 2$
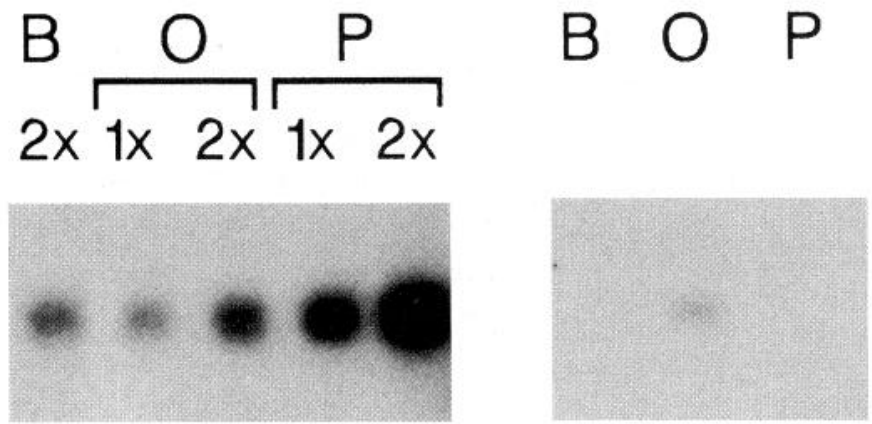

Figure 7. Autophosphorylation of expressed PKCs by oleic acid and TPA. Purified PKCs (Apl I, Apl II, APl II $\Delta E$, and Apl II $\Delta E 2)$ were activated in the presence of $B$ (blank), $O(50 \mu \mathrm{M}$ oleic acid), or $P$ (150 $\mu \mathrm{g} / \mathrm{ml}$ phosphatidylserine and $20 \mathrm{nM}$ TPA) and $\left[\gamma_{-}{ }^{32} \mathrm{P}\right]$ ATP followed by separation on $8.5 \%$ polyacrylamide gels. The amount of PKCs in the $50 \mu \mathrm{l}$ reaction were (in ng): Apl I, $10(1 x), 20(2 x)$; Apl II, 20; Apl II $\Delta \mathrm{E}, 40$ (lx), $80(2 x)$; Apl II $\Delta \mathrm{E} 2,100$. Assuming homogeneity (which is an overestimate, see Fig. 2), the final concentrations of the $1 x$ PKCs in the assay were (in nM): Apl I, 3; Apl II, 4.5; Apl II $\Delta$ E, 12; and Apl II $\Delta E 2,24$.

can substitute for phosphatidylserine in binding to the E region, then synergistic interactions in the activation of $\mathrm{Ca}^{2+}$-independent PKCs may be possible. Alternatively, the E region may physiologically interact with a protein, and phosphatidylserine may be interacting nonspecifically with the hydrophobic interface normally used for protein-protein interactions. Our results also suggest that the E region inhibits Apl II activity by interacting with the phorbol ester-binding domain, C1. A deletion of the E2 domain altered the activation by two different PKC activators, TPA and oleic acid. This effect is unlikely to be attributable to a general instability of the kinase, because activation of Apl II $\Delta \mathrm{E} 2$ by phorbol ester was inhibited, whereas activation by oleic acid was enhanced. Furthermore, the modification of Apl II $\Delta$ E2 activation could be seen with both substrate phosphorylation and autophosphorylation. However, complete removal of the E region did not affect activation by oleic acid or TPA. This apparent contradiction can be explained by postulating the following model for the role of the E region in the activation of Apl II (Fig. 8): the $\mathrm{E}$ region normally inhibits activation of $\mathrm{PKC}$ by diacylglycerol or phorbol esters by binding to $\mathrm{C} 1$; binding of phosphatidylserine to 


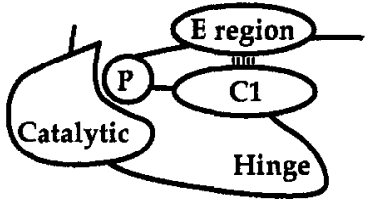

ApI II

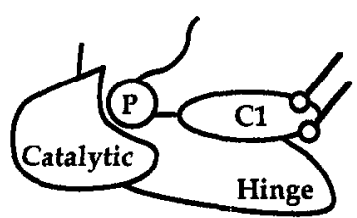

Apl II $\Delta \mathbf{E}$

+ phosphatidylserine

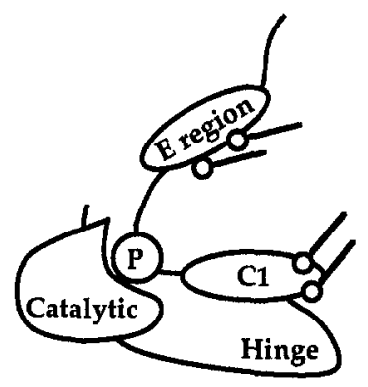

Apl II

+ phosphatidylserine

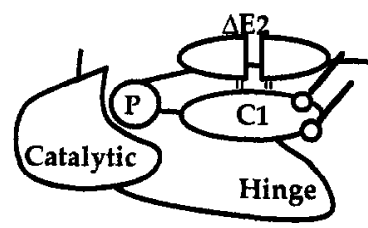

Apl II $\Delta \mathrm{E} 2$ + phosphatidylserine
Figure 8. A model for the role of the E region in regulation of Apl II. In inactivated Apl Il, where the pseudosubstrate $(P)$ is inhibiting the catalytic domain, the $\mathrm{E}$ region would interact with the diacylglycerol-binding, phosphatidylserine-binding $\mathrm{C} 1$ domain, reducing its affinity for diacylglycerol and inhibiting activation of the enzyme. In the presence of phosphatidylserine (O--) or other lipids that could interact with the $E$ region, the inhibitory interaction of the $\mathbf{E}$ region is alleviated and interaction with diacylglycerol can activate the enzyme. In Apl II $\Delta \mathrm{E}$, with the $\mathrm{E}$ region removed, less phosphatidylserine is required for activation of the kinase, as phosphatidylserine is not required to remove the $\mathrm{E}$ region. In Apl II $\Delta \mathrm{E} 2$, phosphatidylserine binding to the $\mathrm{E}$ region is reduced, and its inhibitory role can be seen even in the presence of phosphatidylserine.

the $\mathrm{F}$ region disrupts this interaction, thereby relieving the inhibition of PKC activation. In Apl II $\Delta E 2$, the E region's effects on regulation would persist even in the presence of phosphatidylserine, either because of reduced binding of phosphatidylserine to the $\mathrm{E}$ region in the absence of $\mathrm{E} 2$ (Figs. 4,5), or because the confirmation of the $E$ region bound to phosphatidylserine is altered in the absence of E2. This model is also consistent with the reduction in the amount of phosphatidylserine required for activation of Apl II $\Delta \mathrm{E} 2$ (Fig. 3), because the additional phosphatidylserine usually required for the release of E-region-mediated inhibition has no effect on the activation of Apl II $\Delta E 2$.

Our proposed role for the $\mathrm{E}$ region is similar to suggestions that have been made for the role of the CalB domain in vertebrate $\mathrm{Ca}^{2+}$-activated PKCs. Studies with fusion proteins generated from $\mathrm{Ca}^{2+}$-activated PKCs show that addition of $\mathrm{CalB}$ to a $\mathrm{C} 1$ fusion protein confers a $\mathrm{Ca}^{2+}$ selectivity to phorbol ester binding (I uo and Weinstein, 1993) and decreases the affinity of a fusion protein containing the $\mathrm{C}$-terminal of $\mathrm{C} 1$ for phorbol ester binding (Quest and Bell, 1994). These data are consistent with a model in which the CalB domain interacts with $\mathrm{C} 1$ in the native protein. An interaction between sequences in CalB and sequences in $\mathrm{C} 1$ also is predicted by the pseudoanchoring hypothesis, whereby the site in PKC that normally binds to a PKC receptor is inhibited by a pseudoanchor located in the CalB domain (Ron and Mochly, 1994). We hypothesize that the E region, which shows homology to CalB (Sossin and Schwartz, 1993), plays an analogous role for $\mathrm{Ca}^{2+}$-independent PKCs.

\section{Relevance to physiological models for PKC activation in Aplysia}

Expression of the kinases in a heterologous system has allowed the confirmation of several properties of the kinase that previously had been inferred from nervous system extracts. The ability of $\Lambda \mathrm{pl} \mathrm{I}$ to be stimulated in the absence of $\mathrm{Ca}^{2+}$ is consistent with data from extracts (Sossin and Schwartz, 1992). The $\mathrm{Ca}^{2+}$-independent stimulation of Apl I may account for the observed activation of Apl I by serotonin, which occurs in the absence of an increase in the steady-state $\mathrm{Ca}^{2+}$ levels by serotonin (Eliot et al., 1993). Although Apl I is highly homologous to the vertebrate $\mathrm{Ca}^{2+}$-activated PKCs, differences such as a much shorter aminoterminal V1 region may account for activation of the kinase in the mixed micelle assay in the absence of $\mathrm{Ca}^{2+}$.

Biochemical analyses of the expressed isoforms suggest hypotheses to explain the isoform-specific regulation of PKCs in the Aplysia nervous system. Short-term treatment with serotonin activates Apl I, but not Apl II (Sossin and Schwartz, 1992; Sossin et al., 1994). Presumably, serotonin activates Apl I through the production of diacylglycerol. Because the aftinity for diacylglycerol is modulated by levels of phosphatidylserine (Hannun et al., 1986; Akita et al., 1990), the difficulty in activating Apl II may be related to the high levels of phosphatidylserine required for Apl II activation. Difficulty in activating vertebrate $\mathrm{Ca}^{2+}$-independent PKCs is not seen in cell lines (Kiley et al., 1990; Pfeffer et al., 1991; Strulovici et al., 1991; Olivier and Parker, 1994) and may be specific for the nervous system because of the presence of increased levels of inhibitors of diacylglycerol-binding (Sossin and Schwartz, 1994). Long-term treatments with serotonin transiently activate both Apl I and Apl II (Sossin et al., 1994); perhaps an additional messenger produced by long-term treatments with serotonin relieves the inhibitory effect of the $E$ region.

Some protein kinases that are normally stimulated by second messengers also have the ability to become autonomous or independent of this signal after activation. The most prominent example of this regulation is the $\mathrm{Ca}^{2+}$-calmodulin-dependent kinase, which no longer requires $\mathrm{Ca}^{2+}$-calmodulin (Hanson and Schulman, 1992) when autophosphorylated. An autonomous kinase activity that phosphorylates a PKC substrate is found in Aplysia nervous system extracts, and $>60 \%$ of this activity is removed by immunoprecipitation with an antibody specific for Apl II, but not by an antibody specific for Apl I (Sossin et al., 1994). This activity increases after long- but not short-term treatment with serotonin in the Aplysia nervous system (Sossin et al., 1994). We also observe this activity after expression of Apl II, but not of Apl I, in SF9 cells (Table 2). Autonomous activity of Apl II is not affected by removal of the $E$ region (Table 2), indicating that this region is not required for this activity. The autonomous kinase could be an intrinsic property of Apl II. Alternatively, autonomous activity could be attributable to a post-translational modification such as autophosphorylation, which is present both in Aplysia ganglia and in SF9 cells. Because Apl II expressed in SF9 cells retains the ability to become autonomous, elucidation of the mechanism underlying autonomous activation of Apl II should be possible in this system.

\section{REFERENCES}

Akita Y, Ohno S, Konno Y, Yano A, Suzuki K (1990) Expression and properties of two distinct classes of the phorbol ester receptor family, 
four conventional protein kinase $\mathrm{C}$ types, and a novel protein kinase $\mathrm{C}$. J Biol Chem 265:354-362.

Baxter G, Oto E, Daniel IS, Strulovici B (1992) Constitutive presence of a catalytic fragment of protein kinase $\mathrm{C}$ epsilon in a small cell lung carcinoma cell line. J Biol Chem 267:1910-1917.

Bell RM, Burns DJ (1991) Lipid activation of protein kinase C. J Biol Chem 266:4661-4664.

Braha O, Dale N, Hochner B, Klein M, Abrams TW, Kandel ER (1990) Second messengers involved in the two processes of presynaptic facilitation that contribute to sensitization and dishabituation in Aplysia sensory neurons. Proc Natl Acad Sci USA 87:2040-2044.

Braha O, Edmonds B, Sacktor T, Kandel ER, Klein M (1993) The contributions of protein kinase $\mathrm{A}$ and protein kinase $\mathrm{C}$ to the actions of 5-HT on the L-type $\mathrm{Ca}^{2+}$ current of the sensory neurons in Aplysia. J Neurosci 13:1839-1851.

Brose N, Petrenko AG, Sudhof TC, Jahn R (1992) Synaptotagmin: a calcium sensor on the synaptic vesicle surface. Science 256:1021-1025.

Dekker LV, McIntyre P, Parker PJ (1993a) Altered substrate selectivity of PKC-eta pseudosubstrate site mutants. Febs Lett 329:129-33.

Dekker LV, McIntyre P, Parker PJ (1993b) Mutagenesis of the regulatory domain of rat protein kinase C-eta. A molecular basis for restricted histone kinase activity. J Biol Chem 268:19498-19504.

El Touny S, Khan W, Hannun Y (1990) Regulation of platelet protein kinase $C$ by oleic acid. I Biol Chem 265:16437-16443.

Eliot LS, Kandel ER, Siegelbaum SA, Blumenfeld H (1993) Imaging terminals of Aplysia sensory neurons demonstrates role of enhanced $\mathrm{Ca}^{2+}$ influx in presynaptic facilitation. Nature 361:634-637.

Ghirardi M, Braha O, Hochner B, Montarolo PG, Kandel ER, Dale N (1992) Roles of PKA and PKC in facilitation of evoked and spontaneous transmitter release at depressed and nondepressed synapses in Aplysia sensory neurons. Neuron 9:479-489.

Hannun YA, Bell RM (1987) Mixed micellar assay for phorbol ester binding. Methods Enzymol 141:287-293.

Hannun YA, Loomis CR, Bell RM (1986) Protein kinase C activation in mixed micelles. Mechanistic implications of phospholipid, diacylglycerol, and calcium interdependencies. J Biol Chem 261:7184-7190.

Hanson PI, Schulman H (1992) Neuronal $\mathrm{Ca}^{2+} /$ calmodulin-dependent protein kinases. Annu Rev Biochem 61:559-601.

Huang KP, Chan KF, Singh TJ, Nakabayashi H, Huang FL (1986) Autophosphorylation of rat brain $\mathrm{Ca}^{2+}$-activated and phospholipid-dependent protein kinasc. J Biol Chem 261:12134-12140.

Kaibuchi K, Fukumoto Y, Oku N, Takai Y, Arai K, Muramatsu M (1989) Molecular genetic analysis of the regulatory and catalytic domains of protein kinase C. J Biol Chem 264:13489-13496.

Khan WA, Blobe G, Halpern A, Taylor W, Wetsel WC, Burns D, Loomis C, Hannun YA (1993) Selective regulation of protein kinase C isoenzymes by oleic acid in human platelets. J Biol Chem 268:5063-5068.

Kiley S, Schaap D, Parker P, Hsieh LL, Jaken S (1990) Protein kinase C heterogeneity in $\mathrm{GH} 4 \mathrm{C} 1$ rat pituitary cells. Characterization of a $\mathrm{Ca}(2+)$-independent phorbol ester receptor. J Biol Chem 265:1570415712.

Koide H, Ogita K, Kikkawa U, Nishizuka Y (1992) Isolation and characterization of the epsilon subspecies of protein kinase $\mathrm{C}$ from rat brain. Proc Natl Acad Sci USA 89:1149-1153.

Kruger KE, Sossin WS, Sacktor TC, Bergold PJ, Beushausen S, Schwartz JH (1991) Cloning and characterization of $\mathrm{Ca}(2+)$-dependent and $\mathrm{Ca}(2+)$-independent PKCs expressed in Aplysia sensory cells. J Neurosci 11:2303-2313.

Land M, Islas-Trejo A, Freedman JH, Rubin CS (1994) Structure and expression of a novel, neuronal, protein kinase C (PKC1B) from Caenorhabditis elegans. J Biol Chem 269:9234-9244.

Luo JH, Weinstein IB (1993) Calcium-dependent activation of protein kinase $\mathrm{C}$. The role of the $\mathrm{C} 2$ domain in divalent cation selectivity. $\mathbf{J}$ Biol Chem 268:23580-23584.

Nishizuka Y (1992) Intracellular signaling by hydrolysis of phospholipids and activation of protein kinase C. Science 258:607-614.
Olds JL, Alkon DL (1991) A role for protein kinase C in associative learning. New Biol 3:27-35.

Olivier AR, Parker PJ (1994) Bombesin, platelet-derived growth factor, and diacylglycerol induce selective membrane association and downregulation of protein kinase C isotypes in Swiss $3 \mathrm{~T} 3$ cells. J Biol Chem 269:2758-2763

Osada S, Mizuno K, Saido TC, Akita Y, Suzuki K, Kuroki T, Ohno S (1990) A phorbol ester receptor/protein kinase, nPKC eta, a new member of the protein kinase $\mathrm{C}$ family predominantly expressed in lung and skin. J Biol Chem 265:22434-22440.

Patel G, Stabel S (1989) Expression of a functional protein kinase Cgamma using a baculovirus vector: purification and characterisation of a single protein kinase C iso-enzyme. Cellular Signalling 1:227-240.

Pfeffer LM, Eisenkraft BL, Reich NC, Improta T, Baxter G, Daniel IS Strulovici B (1991) Transmembrane signaling by interferon alpha involves diacylglycerol production and activation of the epsilon isoform of protein kinase $\mathrm{C}$ in Daudi cells. Proc Natl Acad Sci USA 88:79887992.

Quest AF, Bardes ES, Bell RM (1994) A phorbol ester binding domain of protein kinase $\mathrm{C}$ gamma. High affinity binding to a glutathione- $S$ transferase/Cys2 fusion protein. J Biol Chem 269:2953-60.

Quest AF, Bell RM (1994) The regulatory region of protein kinase c-gamma: studies of phorbol ester binding to individual, and combined functional segments expressed as glutathione $S$-transferase fusion proteins indicate a complex mechanism of regulation by phospholipids, phorbol esters, and divalent cations. J Biol Chem 269:20000-20012.

Ron D, Mochly RD (1994) Agonists and antagonists of protein kinase C function, derived from its binding proteins. J Biol Chem 269:2139521398.

Sacktor TC, Schwartz JH (1990) Sensitizing stimuli cause translocation of protein kinase C in Aplysia sensory neurons. Proc Natl Acad Sci USA 87:2036-2039.

Schaap D, Parker PJ (1990) Expression, purification, and characterization of protein kinase C- $\epsilon$. J Biol Chem 265:7301-7307.

Schwartz JH (1993) Cognitive kinases. Proc Natl Acad Sci USA 90:83108313.

Sossin WS, Schwartz JH (1992) Selective activation of Ca(2+)-activated PKCs in Aplysia neurons by 5-HT. J Neurosci 12:1160-1168.

Sossin WS, Diaz AR, Schwartz JH (1993) Characterization of two isoforms of protein kinase $\mathrm{C}$ in the nervous system of Aplysia californica. $\mathrm{J}$ Biol Chem 268:5763-8.

Sossin WS, Schwartz JH (1993) $\mathrm{Ca}^{2+}$-independent protein kinase Cs contain an amino-terminal domain similar to the $\mathrm{C} 2$ consensus sequence. Trends Biochem Sci 18:207-208.

Sussin WS, Scliwarlz JH (1994) Translucation of protein kinase Cs in Aplysia neurons-evidence for complex regulation. Mol Brain Res 24:210-218.

Sossin WS, Sacktor TC, Schwartz JH (1994) Persistent activation of PKC during the development of long-term facilitation in Aplysia. Learning and Memory 1:189-202.

Strulovici B, Daniel IS, Baxter G, Knopf J, Sultzman L, Cherwinski H, Nestor JJ, Webb DR, Ransom J (1991) Distinct mechanisms of regulation of protein kinase $\mathrm{C}$ epsilon by hormones and phorbol diesters. $\mathrm{J}$ Biol Chem 266:168-173.

Sugita S, Goldsmith JR, Baxter DA, Byrne JH (1992) Involvement of protein kinase $C$ in serotonin-induced spike broadening and synaptic facilitation in sensorimotor connections of Aplysia. J Neurophys 68:643-651.

Sugita S, Baxter DA, Byrne JH (1994) Activators of protein kinase c mimic serotonin-induced modulation of a voltage-dependent potassium current in pleural sensory neurons of Aplysia. J Neurophys 72:12401249.

Summers MD, Smith GE (1988) A manual of methods for baculovirus vectors and insect cell culture procedures. Texas Agricultural Experiment Station Bulletin No. 1555. 